Review

\title{
Can Plant Viruses Cross the Kingdom Border and Be Pathogenic to Humans?
}

\section{Fanny Balique ${ }^{1,2}$, Hervé Lecoq ${ }^{2}$, Didier Raoult ${ }^{1,3}$ and Philippe Colson ${ }^{1,3, *}$}

1 Aix-Marseille Université, Unité de Recherche sur les Maladies Infectieuses et Tropicales Émergentes (URMITE) UM 63 CNRS 7278 IRD 3R198 INSERM U1095, Facultés de Médecine et de Pharmacie, 27 boulevard Jean Moulin, 13385 Marseille cedex 05, France; E-Mails: fannybalique@hotmail.fr (F.B.); didier.raoult@gmail.com (D.R.)

2 Institut National de la Recherche Agronomique (INRA), UR 407, Pathologie Végétale, 84140 Montfavet, France; E-Mail: Herve.Lecoq@avignon.inra.fr

3 Institut Hospitalo-Universitaire (IHU) Méditerranée Infection, Pôle des Maladies Infectieuses et Tropicales Clinique et Biologique, Fédération de Bactériologie-Hygiène-Virologie, Centre Hospitalo-Universitaire Timone, Assistance publique - hôpitaux de Marseille, 264 rue Saint-Pierre, 13385 Marseille cedex 05, France

* Author to whom correspondence should be addressed; E-Mail: philippe.colson@univ-amu.fr; Tel.: +33-491-324-375; Fax: +33-491-387-772.

Academic Editors: Thomas Hohn

Received: 13 January 2015 / Accepted: 6 April 2015 / Published: 20 April 2015

Abstract: Phytoviruses are highly prevalent in plants worldwide, including vegetables and fruits. Humans, and more generally animals, are exposed daily to these viruses, among which several are extremely stable. It is currently accepted that a strict separation exists between plant and vertebrate viruses regarding their host range and pathogenicity, and plant viruses are believed to infect only plants. Accordingly, plant viruses are not considered to present potential pathogenicity to humans and other vertebrates. Notwithstanding these beliefs, there are many examples where phytoviruses circulate and propagate in insect vectors. Several issues are raised here that question if plant viruses might further cross the kingdom barrier to cause diseases in humans. Indeed, there is close relatedness between some plant and animal viruses, and almost identical gene repertoires. Moreover, plant viruses can be detected in non-human mammals and humans samples, and there are evidence of immune responses to plant viruses in invertebrates, non-human vertebrates and humans, and of the entry of plant viruses or their genomes into non-human mammal cells and bodies after 
experimental exposure. Overall, the question raised here is unresolved, and several data prompt the additional extensive study of the interactions between phytoviruses and nonhuman mammals and humans, and the potential of these viruses to cause diseases in humans.

Keywords: plant virus; phytovirus; kingdom; human; animal; pathogenicity

\section{Introduction}

Plant viruses are highly prevalent in plants worldwide, including vegetables and fruits, and represent a serious threat to cultivated plants and agriculture production [1]. Nonetheless, in virology, interest has mainly been focused on viruses that cause diseases in humans and other vertebrates. Thus, among the 833,367 articles found in the NCBI Medline database using "virus" as a keyword, 669,837 articles are found when "virus" is cross-searched with "human" or "animal" compared to 27,148 when "virus" is cross-searched with "plant". Nevertheless, plant viruses have been seminal in the field of virology. Tobacco mosaic virus (TMV), which causes mosaic disease in tobacco plants, is usually quoted as the first virus discovered. Indeed, in 1892, Ivanovski demonstrated that it passed through a Chamberland filter that retains bacteria [2] and in 1898, this experiment was independently reproduced by Beijerinck, who interpreted the result as evidence of a new class of agent [3]. Since that time, multiple plant viruses were discovered and currently they are classified in three orders, 22 families, 108 genera and 1019 species [4]. However metagenomics and high-throughput sequencing have already indicated that plant virus diversity has been underestimated $[5,6]$.

It is currently considered that phytoviruses only infect plants and therefore, plant viruses cannot cause disease in humans. In the present review, several issues are raised that challenge this paradigm (Figure 1).

We describe here that some plant and animal viruses are closely related; humans are considerably exposed to plant viruses; plant viruses can enter mammalian cells and bodies and be naturally present in mammals, including humans; and this presence may be non-neutral; plant viruses may trigger events in mammalian cells and elicit immune responses in invertebrates, non-human vertebrates and humans, and was recently associated with clinical symptoms. 

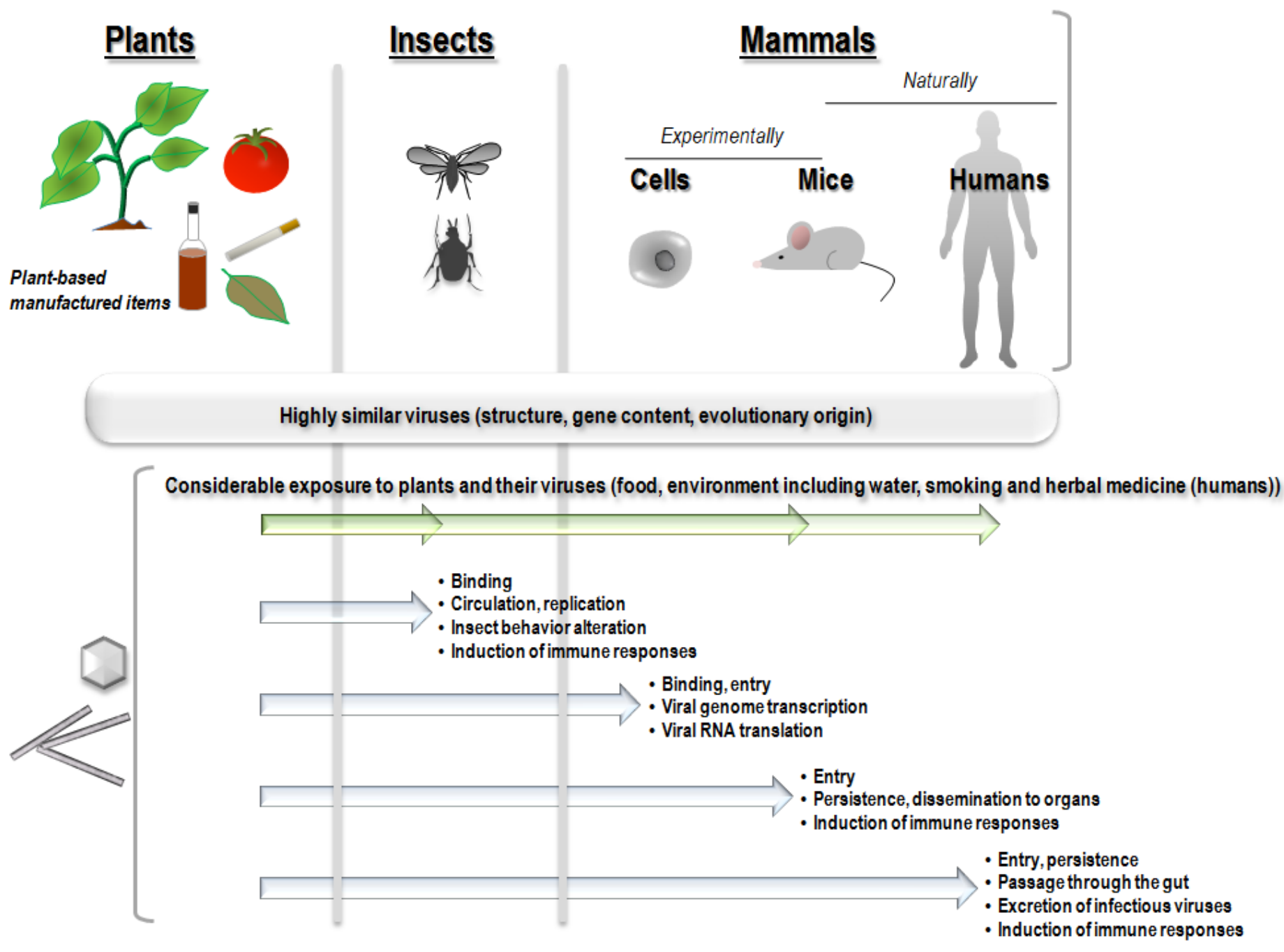

Figure 1. Summary of findings that support border crossing for plant viruses into the invertebrate and vertebrate worlds. 


\section{The Nature of the Border that Segregates Viruses in Plants or Animals}

Viruses are obligate intracellular parasites that are capable of infecting eukaryotes, bacteria and archaea, as well as other viruses [7-9]. Several differences have been discovered between plant and animal viruses, which have led to a paradigm in which a strict border segregates these viruses either to plants or vertebrates. Certainly, some plant and animal viruses display very dissimilar morphologies and genome structures. The majority of phytoviruses are RNA viruses that often harbor multipartite genomes and have either spherical or rod shapes [10]. In contrast, animal viruses more evenly harbor RNA and DNA genomes, which are mainly monopartite, and a majority of virions have a spherical shape [11]. More practically, major differences exist between plant and animal viruses regarding the mechanisms they use to enter into cells and to then propagate from cell to cell [12]. Thus, specific interactions are implicated between animal viruses and cell receptors before viral entry into the cell by endocytosis or fusion, whereas viral egress from the cell occurs via cell lysis or through budding $[13,14]$. In contrast, phytoviruses have to cross the rigid plant cell wall composed mainly of cellulose and pectin, and this step does not implicate specific molecular interactions [15]. Thus, phytoviruses can enter plant cells through epidermal cell injuries inflicted by insects that feed on or penetrate plants but also via infected seeds, or through agricultural practices; others are transmitted directly into the phloem, or by whiteflies, nematodes, mites or fungi [15]. Then, plant viruses propagate from cell to cell through the plasmodesmata, a step that requires a movement protein that is only encoded by the genomes of plant viruses [16-18].

Notwithstanding these differences, breaking down the kingdom border is far from being unusual for some plant viruses. Indeed, $\approx 80 \%$ of known plant viruses depend on insect vectors for their transmission, although only a small proportion of insect-transmitted viruses are able to replicate in their insect vector $[10,12,19]$. The majority of these insect vectors are classified into the order Hemiptera, which notably encompasses aphids, whiteflies, thrips, leafhoppers and planthoppers [10]. These insects can disseminate viruses to plants and animals thereby creating virus families with wide host ranges. The ability of some plant viruses to infect invertebrate vectors may be related to the presence of a limited number of proteins. For Potato yellow dwarf virus, the permissivity of insect cells depends on the presence of a glycosylated protein G [20], and for Rice dwarf virus a mutation of the P2 protein may abolish virus infectivity in the insect, and its transmission capacity [21]. There are two main modes of plant virus transmission by insects: non-circulative transmission, where the virus remains attached to the cuticle of the insect stylet or the anterior digestive tract of the insect vector but does not cross insect body barriers, and circulative transmission, where the virus crosses insect body barriers and enters its circulatory system and then accumulates in the salivary glands [12,22]. This specific viral adhesion to the cuticle can involve either capsid proteins that allow adhesion to insect receptors, as for Cucumber mosaic virus (CMV) [23], or through other viral proteins called helper components. In the case of potyviruses, one conserved domain (PTK) of the helper component protein (HC) has been shown to interact with a conserved capsid domain (DAG), and another conserved domain of HC is believed to interact with hypothetical receptors on the insect stylet [12]. In circulative transmission, infected saliva transmits the virus to healthy plants via insect feeding. In circulative non-propagative transmission, viruses only transit through the insect body but do not replicate. Members of the families Luteoviridae, Nanoviridae and Geminiviridae are transmitted to plants via this mode. Tomato yellow leaf curl virus 
(TYLCV), which belongs to family Geminiviridae, is suspected to multiply in its insect vector, Bemisia tabaci, and transovarial and sexual transmission of this virus and its DNA have been observed [24-26]. In circulative propagative transmission, viruses multiply in the insect vector and can be found in different organs and tissue such as muscle, nervous tissue, connective tissue, salivary glands and fat, and transovarial transmission has been described for some viruses [27]. Viruses transmitted via the circulative propagative mode include members of the family Rhabdoviridae (genera Cytorhabdovirus and Nucleorhabdovirus), Reoviridae (genera Phytoreovirus, Fijivirus and Oryzavirus), Tymoviridae (genus Marafivirus), Bunyaviridae (genus Tospovirus), and the genus Tenuivirus [10]. The fact that some plant viruses can replicate in their insect vectors makes them somewhat insect viruses as well, and phytoviruses involved in circulative propagative transmission are generally considered to be insect viruses that have acquired the ability to infect another reservoir, namely plants, during evolution. Moreover, in insects, alterations in behavior have been observed in association with infection by several plant viruses, suggesting that these viruses may be pathogenic for the insects (Figure 1). Tomato spotted wilt virus (TSWV) has been shown to directly alter the male feeding behavior of Frankliniella occidentalis [28]. In addition, infection of Bemisia tabaci by TYLCV was associated with a reduction in insects of longevity and fecundity [29], and recently, Tobacco ringspot virus (TRSV), a pollen-borne nepovirus, was shown to replicate and produce virions in several body parts in Apis mellifera, honeybees [30].

These previous findings question if some plant/insect viruses may further cross the border into the animal world to enter and replicate in vertebrates. In fact, with respect to the phylogenetic distance between plants on the one hand and insects or mammals including humans on the other hand, it appears just as complex for viruses to cross the kingdom barrier from plants to insects than from plants to any mammals. Indeed, phylogenetic distance between plants and insects, which are natural and possible hosts for some plant viruses, is far greater than the distance between insects and vertebrates (Figure 2) [31,32].

\section{Close Relatedness between Plant and Animal Viruses and Evidence for Common Origins}

The distribution of plant and animal viruses within the currently defined taxons indicates that some plant and animal viruses belong to same viral families (Table 1).

Indeed, family Reoviridae includes several genera infecting a variety of animals and three genera (Phytoreovirus, Fijivirus and Oryzavirus) infecting both plants and insects [11,35]. In addition, most of the phytoviruses that multiply in insect vectors and are transmitted through the circulative mode are classified in families that also contain animal viruses. This is true for family Reoviridae, which includes rotavirus, a major cause of gastroenteritis in humans [36], family Rhabdoviridae, which notably includes rabies virus [37], and family Bunyaviridae, which encompasses human pathogens such as Hantaan virus and Toscana virus [38-40]. Within the family Rhabdoviridae, genomic organization indicates that some plant viruses of genera Nucleorhabdovirus and Cytorhabdovirus differ from animal viruses of genera Vesiculovirus, Lyssavirus, Novirhabdovirus and Ephemerovirus only by the presence of an additional gene coding for a movement protein, a protein essential for the systemic spread of the virus in the host plant $[17,18,37,41]$. In addition among the genera of animal rhabdoviruses, many viruses are characterized as arboviruses and can be transmitted by insects vectors. The Vesicular stomatitis virus (VSV) which belongs to genus Vesiculovirus, can be transmitted to domestic swine through infected black-flies (Simulium vittatum) [42]. Notably, reoviruses, rhabdoviruses and bunyaviruses, in addition 
to containing members infecting either plants or insects or vertebrates, all have virions with an envelope derived from the host membrane. This, together with membrane-inserted viral-encoded proteins that interact with cell surface receptors, facilitates entry into animal host cells.

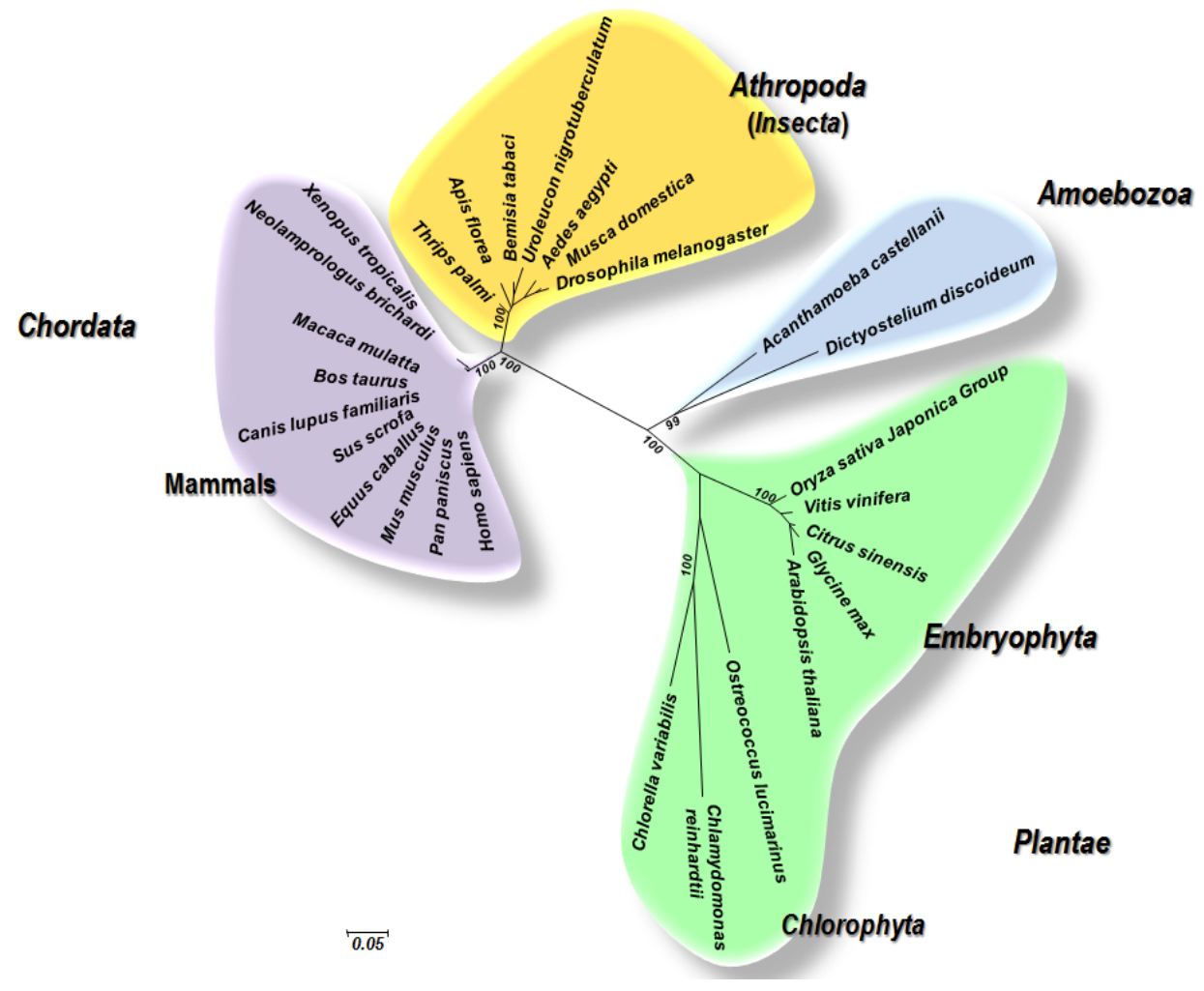

Figure 2. Phylogeny reconstruction based DNA-dependent RNA polymerase subunit 2 for some members of the domain Eukaryota, including land plants, insects and human and other mammals. Phylogenetic analysis was performed using the maximum likelihood method with the MEGA5 software [33], and involved a curated alignment of 27 sequences composed of 1038 amino acid positions. Only bootstrap values at major nodes are shown. Scale bar represents the number of estimated changes per position for a unit of branch length. Sequences from the NCBI GenBank protein sequence database [34] that were used included: CAA79527, Arabidopsis thaliana; XP_006487405, Citrus sinensis; XP_636812, Dictyostelium discoideum AX4; EEE59590, Oryza sativa Japonica Group; XP_005844289, Chlorella variabilis; XP_003547482, Glycine max; BAJ78717, Bemisia tabaci; XP_002274051, Vitis vinifera; EJY57456, Aedes aegypti; XP_003129085, Sus scrofa; CAA29180, Drosophila melanogaster; XP_001415447, Ostreococcus lucimarinus CCE9901; XP_002937598, Xenopus (Silurana) tropicalis; AAH38472, Mus musculus; XP_001916826, Equus caballus; NP_000929, Homo sapiens; XP_003806546, Pan paniscus; XP_006781988, Neolamprologus brichardi; XP_532382, Canis lupus familiaris; XP_005188839, Musca domestica; EHH25986, Macaca mulatta; XP_003696177, Apis florea; BAJ78718, Uroleucon nigrotuberculatum; XP_004348530, Acanthamoeba castellanii str. Neff; BAJ78713, Thrips palmi; NP_001092552, Bos taurus; AAY89365, Chlamydomonas reinhardtii. 
Table 1. Virus families composed of plant and humans or non-human animal viruses.

\begin{tabular}{|c|c|c|c|c|c|c|}
\hline Genome & $\begin{array}{c}\text { Genome } \\
\text { Segmentation }\end{array}$ & Virion Shape & Family & Sub-Family & Genus & Hosts \\
\hline \multirow[t]{3}{*}{$\begin{array}{l}\text { RNA, single-stranded, } \\
\text { positive }\end{array}$} & Monopartite & Icosahedral & \multirow{3}{*}{ Tymoviridae } & & Tymovirus & Plants \\
\hline & Monopartite & & & & Maculavirus & Plants \\
\hline & Monopartite & & & & Marafivirus & Plants and insects \\
\hline \multirow{5}{*}{$\begin{array}{l}\text { RNA, single-stranded, } \\
\text { negative or } \\
\text { ambisense }\end{array}$} & Monopartite & $\begin{array}{c}\text { Pleomorphic, } \\
\text { globular }\end{array}$ & \multirow{5}{*}{ Bunyaviridae } & & Hantavirus & Mammals \\
\hline & Monopartite & & & & Bunyavirus & Mammals \\
\hline & Monopartite & & & & Nairovirus & Mammals \\
\hline & Monopartite & & & & Phlebovirus & Mammals \\
\hline & Tripartite & & & & Tospovirus & Plants and insects \\
\hline \multirow{8}{*}{$\begin{array}{l}\text { RNA, single-stranded } \\
\text { negative }\end{array}$} & Monopartite & bacilliform & \multirow{7}{*}{ Rhabdoviridae } & & Lyssavirus & Vertebrates \\
\hline & Monopartite & & & & Vesiculovirus & Vertebrates \\
\hline & Monopartite & & & & Ephemerovirus & Vertebrates \\
\hline & Monopartite & & & & Novirhabdovirus & Vertebrates (fishes) \\
\hline & Monopartite & & & & Cytorhabdovirus & Plants and insects \\
\hline & Monopartite & & & & Nucleorhabdovirus & Plants and insects \\
\hline & Bipartite & & & & Dichorhabdovirus & Plants \\
\hline & Multipartite & Flexuous & - & & Tenuivirus & Plants and insects \\
\hline
\end{tabular}


Table 1. Cont

\begin{tabular}{|c|c|c|c|c|c|c|}
\hline Genome & $\begin{array}{c}\text { Genome } \\
\text { Segmentation }\end{array}$ & Virion Shape & Family & Sub-Family & Genus & Hosts \\
\hline \multirow[t]{15}{*}{ RNA, double-stranded } & Monopartite & icosahedral & \multirow{6}{*}{ Reoviridae } & \multirow[t]{6}{*}{ Sedoreovirinae } & Cardoreovirus & Crustaceans \\
\hline & Monopartite & & & & Mimoreovirus & $\begin{array}{l}\text { Photosynthetic marine } \\
\text { protists }\end{array}$ \\
\hline & Monopartite & & & & Orbivirus & Arthropod, vertebrates \\
\hline & Monopartite & & & & Rotavirus & Vertebrates \\
\hline & Monopartite & & & & Seadornavirus & $\begin{array}{c}\text { Invertebrates and } \\
\text { vertebrates }\end{array}$ \\
\hline & Multipartite & & & & Phytoreovirus & Plants and insects \\
\hline & Monopartite & & & \multirow[t]{9}{*}{ Spinareovirinae } & Aquareovirus & $\begin{array}{c}\text { Aquatic vertebrates and } \\
\text { invertebrates }\end{array}$ \\
\hline & Monopartite & & & & Coltivirus & $\begin{array}{c}\text { Invertebrates and } \\
\text { vertebrates }\end{array}$ \\
\hline & Monopartite & & & & Cypovirus & Insects \\
\hline & Monopartite & & & & Dinovernavirus & Insects \\
\hline & Monopartite & & & & Idnoreovirus & Insects \\
\hline & Monopartite & & & & Mycoreovirus & Fungi \\
\hline & Monopartite & & & & Orthoreovirus & Vertebrates \\
\hline & Multipartite & & & & Fijivirus & Plants and insects \\
\hline & Multipartite & & & & Oryzavirus & Plants and insects \\
\hline
\end{tabular}


In addition, Cowpea mosaic virus (CPMV), which is a member of family Secoviridae, shares structural features and genetic organization with animal picornaviruses such as polioviruses, coxsackie viruses and Theiler's murine encephalomyelitis virus (TMEV), which supports the hypothesis that these plant and animal viruses might derive from a common ancestor $[43,44]$. In addition, pararetroviruses include plant viruses from the family Caulimoviridae, which consists of the only plant viruses with a double-stranded (ds) DNA genome, as well as animal viruses that belong to the family Hepadnaviridae, which includes hepatitis B virus [45]. Similarly, hepatitis E virus, a leading cause of acute hepatitis in humans, was grouped with Beet necrotic yellow vein virus, a plant virus that belongs to the genus Benyvirus, based on phylogeny of RNA polymerases [46]. Recently, endogenous viral elements (EVEs) from plant RNA viruses were detected in 14 insect genomes [47]. Interestingly, EVE sequences very close to those of phytoviruses of the family Virgaviridae were detected in the genome of a mosquito, Aedes aegypti; a fly, Drosophila rhopaloa; and a bee, Bombyx terrestris. The EVE detected in Aedes aegypti was similar to the tobamovirus genome, which is very surprising as no insect vector is known for tobamoviruses. These insects might have possibly interacted with these viruses during nectar feeding on infected plants. Moreover, Dolja and Koonin noted that there are multiple related groups of viruses in plant and animals and that the genes involved in viral genome replication and expression are conserved between plant and animal viruses, whereas genes implicated in virus-host interactions are not [48]. These authors described three scenarios for the evolution of related viruses in plants and animals: (i) evolution of these viruses from a common ancestral virus predating plant-animal divergence; (ii) horizontal transfers of viruses between plants and animals; and (iii) parallel evolution of related viruses from related ancestral genetic elements [48]. For instance, RNA-dependent RNA polymerase (RdRp) of positive single-stranded as well as dsRNA viruses that infect plants or animals have conserved amino acid sequences and three-dimensional structures, which suggests common roots for these viruses $[46,48,49]$. In addition, the rolling-circle replication endonuclease (RCRE), a key enzyme for the replication of single-stranded DNA viruses, is conserved in plant viruses (families Geminiviridae and Nanoviridae) and in animal viruses (families Parvoviridae and Circoviridae) [48,50,51]. Also, Gibbs et al. suggested that a plant nanovirus switched hosts to infect a vertebrate and then recombined with a vertebrate-infecting picorna-like virus [52,53]. This host-switch might have occurred through exposure of a vertebrate to the sap of an infected plant. Lastly, the delta agent, typically called hepatitis delta virus (HDV), which is a human pathogen that needs the envelope protein of hepatitis $B$ virus for its replication, displays considerable similarities with viroids [59]. Viroids are plant pathogens smaller and simpler than plant viruses, only composed of a naked single-stranded circular non-coding RNA of $\approx 250-400$ nucleotides with a rod-like secondary structure due to self-complementary regions [54]. Regarding the HDV genome, it is 1700 nucleotide-long, which is the smallest size among known animal viruses, and it encodes a single protein (the delta antigen) $[55,56]$. This genome is a covalently closed circular single-stranded molecule that might have a rod-like secondary structure, as approximately two-thirds of the bases are paired [55], and it has been hypothesized that HDV may have evolved from the fusion of a viroid with an animal gene [57,58]. Indeed, Brazas and Ganem isolated and cloned a cellular gene that encodes a protein named delta-interacting protein A (DIPA), which shares 56\% amino acid similarity with the delta antigen [57]. These authors hypothesized that DIPA and HDV antigen-encoding RNA may share a common ancestor that could have been captured by a viroid-like RNA. 


\section{Exposure of Non-Human Animals and Humans to Plant Viruses}

Non-human animals and humans that eat fruits and leafy vegetables are exposed to phytoviruses. Thus, plant viruses are most likely highly prevalent in wild and cultivated plants, including fruits and vegetables (Figure 1). For example, it was found that approximately $60 \%$ of plants in a geographical area of Costa Rica (encompassing a total of 7000 plant species) harbored plant viruses [5]. TMV may infect over 150 plants including tomatoes, peppers, and cucumbers [59]. Tomato bushy stunt virus (TBSV), a tombusvirus, is an important pathogen of tomatoes and other plants, and it was observed to reach a concentration of approximately $200 \mathrm{mg}$ per $\mathrm{kg}$ of infected leaves in experimental hosts such as Nicotiana clevelandii [60]. Moreover, this virus can remain infectious despite being frozen for several years, and its thermal inactivation point is $80-90{ }^{\circ} \mathrm{C}$ [61]. Some phytoviruses are also present in food products, and we detected Pepper mild mottle virus (PMMoV) RNA in 57\% of 28 pepper-based food items and demonstrated that the PMMoV in these food items was still able to induce plant infection [62]. The viral titer can be very high in these products. For example, we detected up to $10^{7}$ viral copies $/ \mathrm{mL}$ in Tabasco sauce [62]. Hence, it can be anticipated that plant viruses could be found in human faeces. Humans can also be exposed to plant viruses through ingestion of herbal medicine. In some countries in Asia and sub-Saharan Africa, $80 \%$ of the population uses traditional medicine for primary health care, with herbal treatment being the most used traditional medicine [63]. Smoking is another risk factor for exposure to plant viruses, TMV being present and stable in the smoked tobacco [64-67] and resistant to manufacturing processes [68]. Mean TMV RNA titer was found to be $9.5 \log _{10}$ RNA copies/cigarette and $3.8 \log _{10}$ RNA copies/mL of smokers' saliva [69].

Finally, plant viruses are also detected in the environment including in the soil, water, and clouds [70-72]. ToMV was found in water draining in forest stands in New York State [73], in 140,000-year-old glacial ice from drill sites in Greenland [74], and also in fogs and clouds [75]. PMMoV has been found to be widespread and abundant in wastewater in the United States and in sewage and river water in Germany, which suggests that this virus can be a good indicator of human fecal pollution [76,77], and it was recently detected in $76 \%$ of 184 source water samples collected from 30 drinking water treatment plants in Japan between 2008-2011, at concentrations up to $3.5 \log _{10}$ copies/mL [78]. In addition, TBSV was recovered from the Thames river and several other English rivers [79], ToMV and Melon necrotic spot virus have been detected in irrigation systems in Slovenia and Spain, respectively [80,81], and Cucumber green mottle mosaic virus (CGMMV) was recovered from the Yamuna River in India, and the recovered viruses were infectious to host plants [82]. This capability to persist in the environment enhances the dispersion and transmission of these viruses.

\section{Evidence of the Natural Presence and Persistence of Plant Viruses in Non-Human Mammals}

The natural presence of plant viruses in non-human mammals has been reported in several studies (Table 2; Figures 1 and 3), and these mammals may spread infectious phytoviruses that are stable in the gastrointestinal tract through their contaminated stools [83,84]. 
Table 2. Plant viruses detected in humans or non-human mammals or shown to interact in experimental in vitro studies with humans or non-human mammals.

\begin{tabular}{|c|c|c|c|c|c|c|}
\hline $\begin{array}{c}\text { Nucleic } \\
\text { Acid }\end{array}$ & Family & Genus & Species & Vertebrate Cells & Mammals & Humans \\
\hline ssRNA+ & Alphaflexiviridae & N.a. & & & Mouse, vole and rat stools [85] & \\
\hline ssRNA+ & Bromoviridae & Ilarvirus & Prunus necrotic ringspot virus & & & Stools [86] \\
\hline ssRNA+ & Closteroviridae & Closterovirus & Citrus tristeza virus & & & Stools [87] \\
\hline \multirow[t]{2}{*}{ ssRNA+ } & Luteoviridae & N.a. & N.a. & & Bat guano [88] & \\
\hline & & N.a. & N.a. & & Mouse, vole and rat stools [85] & \\
\hline \multirow{4}{*}{ ssRNA+ } & & Comovirus & Cowpea mosaic virus & Human huvec cells [44] & & \\
\hline & & Comovirus & Cowpea mosaic virus & Human KB cells [44] & & \\
\hline & & N.a. & N.a. & & Bat guano [88] & \\
\hline & & N.a. & N.a. & & Mouse, vole and rat stools [85] & \\
\hline \multirow[t]{3}{*}{ ssRNA+ } & & Sobemovirus & Rice yellow mottle virus & & Cows, donkeys and grass rats [89] & \\
\hline & & Sobemovirus & Subterranean clover mottle virus & & Sheep [90] & \\
\hline & & Sobemovirus & Cocksfoot mottle virus & & & Stools $[86]$ \\
\hline \multirow[t]{10}{*}{ ssRNA+ } & Tombusviridae & Tombusvirus & Tomato bushy stunt virus & & & Stools $[60]$ \\
\hline & & Panicovirus & Panicum mosaic virus & & & Stools [86] \\
\hline & & Carmovirus & Melon necrotic spot virus & & & Stools $[86]$ \\
\hline & & Carmovirus & Galinsoga mosaic virus & & & Stools [86] \\
\hline & & Carmovirus & Carnation mottle virus & & & Stools [86] \\
\hline & & Necrovirus & Tobacco necrosis virus & & & Stools $[86]$ \\
\hline & & Necrovirus & Olive latent virus 1 & & & Stools $[86]$ \\
\hline & & Aureusvirus & Pothos latent virus & & & Stools $[86]$ \\
\hline & & Aureusvirus & Johnsongrass chlorotic stripe mosaic virus & & & Stools $[86]$ \\
\hline & & Avenavirus & Oat chlorotic stunt virus & & & Stools [86] \\
\hline
\end{tabular}


Table 2. Cont

\begin{tabular}{|c|c|c|c|c|c|c|}
\hline $\begin{array}{l}\text { Nucleic } \\
\text { Acid }\end{array}$ & Family & Genus & Species & Vertebrate Cells & Mammals & Humans \\
\hline & & Machlomovirus & Maize chlorotic mottle virus & & & Stools $[86]$ \\
\hline & & N.a. & N.a. & & Mouse, vole and rat stools [85] & \\
\hline \multirow[t]{14}{*}{ ssRNA+ } & Tymoviridae & Marafivirus & $\begin{array}{c}\text { Grapevine asteroid mosaic-associated } \\
\text { virus }\end{array}$ & & & Stools $[86]$ \\
\hline & & Marafivirus & Maize rayado fino virus & & & Stools $[86]$ \\
\hline & & Marafivirus & Grapevine rupestris vein feathering virus & & & Stools $[86]$ \\
\hline & & Marafivirus & Oat blue dwarf virus & & & Stools $[86]$ \\
\hline & & Maculavirus & Grapevine fleck virus & & & Stools $[86]$ \\
\hline & & Maculavirus & Grapevine red globe virus & & & Stools $[86]$ \\
\hline & & Tymovirus & Chayote mosaic tymovirus & & & Stools $[86]$ \\
\hline & & Tymovirus & Kennedya yellow mosaic virus & & & Stools $[86]$ \\
\hline & & Tymovirus & Physalis mottle virus & & & Stools $[86]$ \\
\hline & & Tymovirus & Poinsettia mosaic virus & & & Stools $[86]$ \\
\hline & & Tymovirus & Eggplant mosaic virus & & & Stools $[86]$ \\
\hline & & Tymovirus & Ononis yellow mosaic virus & & & Stools $[86]$ \\
\hline & & N.a. & N.a. & & Bat guano [88] & \\
\hline & & N.a. & N.a. & & Mouse, vole and rat stools [85] & \\
\hline \multirow[t]{9}{*}{ ssRNA+ } & Virgariridae & Tobamovirus & Tobacco mosaic virus & Hela cells [91] & Mice [92] & Stools $[86,87]$ \\
\hline & & & & Mice splenocyte [93] & & Skin [94] \\
\hline & & & & Mice bone marrow cells [92] & & Thoracentesis fluids [95] \\
\hline & & & & & & Saliva [69] \\
\hline & & Tobamovirus & Pepper mild mottle Virus & & & Stools $[86,87]$ \\
\hline & & Tobamovirus & Cucumber green mottle mosaic virus & & Cows stools [96] & \\
\hline & & Tobamovirus & Tomato mosaic virus & & & Stools $[86]$ \\
\hline & & Tobamovirus & Ribgrass mosaic virus & & & Stools $[86]$ \\
\hline & & Tobamovirus & Turnip vein-clearing virus & & & Stools $[86]$ \\
\hline
\end{tabular}


Viruses 2015, 7

Table 2. Cont.

\begin{tabular}{|c|c|c|c|c|c|c|}
\hline $\begin{array}{c}\text { Nucleic } \\
\text { Acid }\end{array}$ & Family & Genus & Species & Vertebrate Cells & Mammals & Humans \\
\hline & & Tobamovirus & Tobacco mild green mosaic virus & & & Stools $[86]$ \\
\hline & & Tobamovirus & Odontoglossum ringspot virus & & & Stools $[86]$ \\
\hline & & Tobamovirus & Paprika mild mottle virus & & & Stools $[86]$ \\
\hline & & Tobamovirus & Kyuri green mottle mosaic virus & & & Stools [87] \\
\hline & & Tobamovirus & Crucifer tobamovirus & & & Stools [87] \\
\hline & & Tobamovirus & Obuda pepper virus & & & Stools $[86]$ \\
\hline & & Tobamovirus & Nigerian tobacco latent virus & & & Stools $[86]$ \\
\hline \multirow[t]{2}{*}{ dsRNA } & Partitiviridae & N.a. & N.a. & & Bat guano [88] & \\
\hline & & N.a. & N.a. & & Mouse, vole and rat stools [85] & \\
\hline dsDNA & Phycodnaviridae & Chlorovirus & Acanthocystis turfacea chlorella virus 1 & & Mouse [72] & Oropharynx samples [72] \\
\hline ssDNA & Nanoviridae & N.a. & N.a. & & Mouse, vole and rat stools [85] & \\
\hline ssDNA & Geminiviridae & N.a. & N.a. & & Mouse, vole and rat stools [85] & \\
\hline
\end{tabular}




\section{Insects (order Hemiptera)

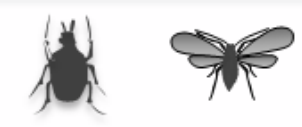

Non-circulative transmission

Circulative transmission

Circulative non-propagative transmission

e.g. Luteoviridae, Nanoviridae, Geminiviridae

Circulative propagative transmission

e.g. Rhabdoviridae, Reoviridae, Bunyaviridae

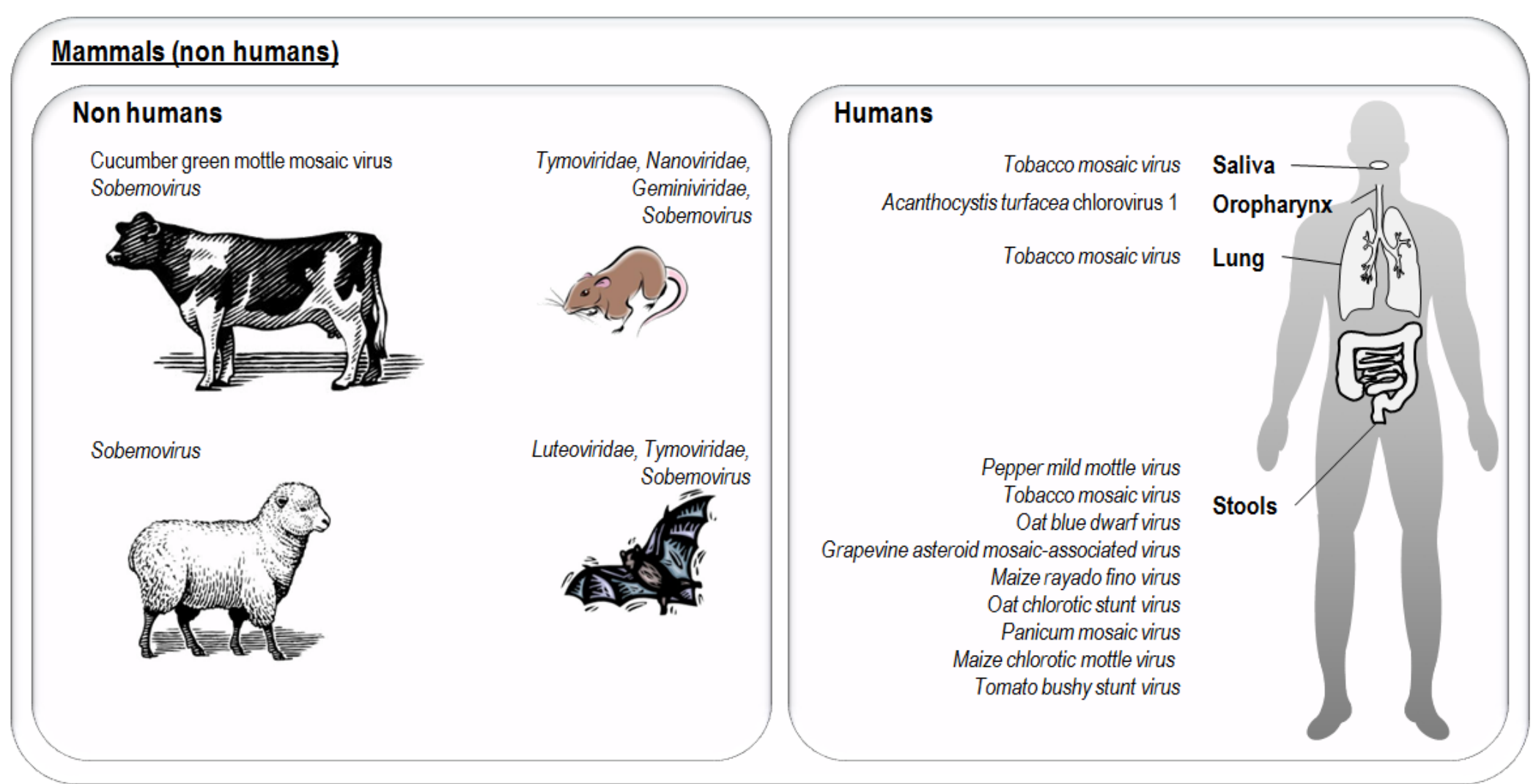

Figure 3. Detection of plant viruses in insects and mammals including humans. 
In 1988, CGMMV, a tobamovirus, was recovered in cow manure three days after feeding with infected cucumbers [96]. More recently, $46 \%$ of sequences from a Californian bat guano virome and $27 \%$ of a Texan bat guano virome were linked to members of Luteoviridae and Sobemovirus [88]. In the stools of wild rodents, $3.4 \%$ of virome sequences were linked to phytoviruses of families Nanoviridae, Geminiviridae, and Alphaflexiviridae [85]. Members of the families Partitiviridae, Tymoviridae and Secoviridae were also observed in bat and rodent stools [85,88]. PMMoV was detected by qRT-PCR in 7/15 fecal samples from chicken, 1/10 from geese and 1/6 from cows, at titers up to $3.1 \log _{10}$ copies/mg [97]. In addition, the transmission of sobemoviruses by animals was also reported; the Rice yellow mottle virus can be transmitted by cows, donkeys and grass rats [89], and the Subterranean clover mottle virus by sheep (Table 2) [90].

\section{Presence of Plant Viruses in Human Samples}

In 1982, TBSV, a Tombusviridae member, was purified and ingested by human volunteers. The inoculation of their feces on Chenopodium quinoa leaves induced signs of viral infection. It was also hypothesized that TBSV could be spread by humans in river water through sewage $[60,79]$. Moreover, several studies conducted during the 1950s-1970s reported on the presence of TMV in human lungs and its role in lung cancer [64,98-100]. Thus, TMV was recovered from lung cancerous matter [94] (Figure 3), from 15/35 sputum specimens and 1/4 thoracentesis fluids from cigarette smokers with a history of pulmonary disease [95], but another study failed to confirm this hypothesis [101]. TMV was also detected in the lungs of active or passive smokers through inoculation to tobacco leaves [102,103]. Nevertheless, this ability for a very stable virus such as TMV to retain infectivity does not demonstrate that it replicated within a smoker's respiratory fluids or organs. Also, tobacco plant DNA was recently detected in the bronchoalveolar lavage of intubated patients [104]. The issue of plant virus presence and pathogenicity in humans was fueled in 2006 by the discovery by metagenomics that plant viruses were the most prevalent RNA viruses in human feces (Table 2; Figure 3) [86]. The most abundant virus was PMMoV, but this study identified 35 phytoviruses including TMV. Up to $10^{9}$ virions of PMMoV were detected per gram of dry weight of fecal matter. We sought PMMoV using real-time PCR in feces and detected it from 22 (7.2\%) of 304 adults [62]. We also observed a correlation between PMMoV presence in stools and some clinical signs. Indeed, fever was observed in 39\% of PMMoV-positive versus 13\% of PMMoV-negative patients ( $p=0.042$ ), and abdominal pain were reported in 39\% of PMMoV-positive versus $7 \%$ of PMMoV-negative patients $(p=0.008)$, and pruritus was also independently correlated with PMMoV RNA detection in feces in multivariate analysis. Nevertheless, no causal relationship was demonstrated between PMMoV presence and clinical symptoms; especially, abdominal pain may be related to the consumption of pepper or pepper-based food items, which was not assessed in our study. Nonetheless, taken together, these findings support the hypothesis that PMMoV may not be only a transient inhabitant of the human gut but, alternatively, its presence may be non-neutral. In another study, PMMoV was found by qRT-PCR in 19/20 healthy human fecal samples at titers up to $7.0 \log _{10}$ viral RNA copies/mg [97]. In addition, using metagenomics, tobamoviruses were detected in stools from Japan (Table 2; Figure 3) [87] and TMV RNA was retrieved in stools collected from South Asian children with non-polio acute flaccid paralysis [105], concurrently with human pathogens, which were presumed to be responsible for the observed symptoms. We also detected TMV RNA in $45 \%$ of saliva samples from 
smokers whereas all saliva samples from non-smokers tested negative, and we found that all 47 cigarettes from different brands were positive for TMV (Figure 1) [69].

Finally, two recent studies described the presence of algae viruses in humans. Stepanova et al. reported such viruses by culturing on the marine diatom Phaeodactylum tricornutum in 16 of 41 (39\%) pooled cervicovaginal secretions from women from Ukraine presenting with colpitis (6 of 11), uterus fibroids (5 of 14), or uterus cervical erosion (5 of 16) [71]. More strikingly, it was reported in 2014 that many metagenomic sequences retrieved from human oropharyngeal samples matched to Acanthocystis turfacea chlorella virus 1 (ATCV-1), a phycodnavirus that infects green algae [72]. Moreover, ATCV1-liked DNA was subsequently detected from $44 \%$ of 92 oropharyngeal samples by real-time PCR, and PCR positivity was significantly correlated with altered cognitive functions. ATCV-1 inoculation to mice also impaired cognitive functions, and significantly altered hippocampus gene expression, as assessed 26 weeks post-exposure.

\section{Immune Responses to Plant Viruses in Invertebrates, Non-Human Vertebrates and Humans}

Plant viruses were found to trigger immune responses in invertebrates, vertebrates and humans, which might only reflect a history of exposure to foreign proteins and does not necessarily imply a role of the plant virus in pathogenesis. TSWV infection has been shown to induce a strong immune response in Frankliniella occidentalis, its major insect vector [106]. In addition, CPMV has been shown to induce humoral and persistent systemic and local immune responses in mice as detected by ELISA following oral administration [107], mice inoculated with Potato Virus $Y$ developed antibodies to the virus [108], and we detected anti-TMV total antibodies in serum samples from mice inoculated intratracheally with TMV, seven days after inoculation [92]. In another work, inoculation to mice of ATCV-1, a phycodnavirus that infects green algae, was associated with the appearance of antibodies to this virus in $36 \%$ of the mice [72]. Finally, we found anti-PMMoV antibodies in humans, significantly more frequently in serum samples from patients with PMMoV, and, than in serum samples from controls [62], and anti-TMV IgG were recently detected by another team at a higher level in smokers than in non-smokers [109].

\section{Evidence of the Entry of Plant Viruses or Their Genomes into Non-Human Mammal Cells and Bodies after Experimental Exposure}

Experimental data are available on the entry of plant viruses or their genomes into non-human mammal cells and bodies, although this was obtained through artificial means and did not lead to viral propagation in absence of an exogenous host factor. Indeed, viral replication implies the formation and release of a viral progeny, following virus entry in the target host cells. In vitro analyses have demonstrated that TMV RNA can be translated in Xenopus laevis oocytes [110] (Figure 1). TMV was used to model the defense mechanisms of HeLa cells against virus invasion, which allowed detecting an accumulation of TMV proteins on autophagosomal membranes, and observing TMV-resembling virions in the cellular cytoplasm [91]. In addition, we recently observed that infectious TMV could enter and persist in mouse lungs inoculated via the intratracheal route, as determined using immunohistochemistry, electron microscopy, real-time RT-PCR and sequencing; anti-TMV antibody seroconversions were observed in mice and TMV was detected in murine bone marrow-derived macrophages following experimental inoculation [92]. Moreover, in 2009, Koudelka et al. demonstrated that CPMV binds to the 
vimentin surface protein and enters mammalian cells, including endothelial, circulating cells and HeLa cells [44]. The animal picornavirus TMEV has also been shown to interact directly with vimentin [111], and mammalian Porcine reproductive and respiratory syndrome virus also uses surface vimentin for entry in host cells [112]. Thus, CPMV and animal viruses share the processes of entry into mammalian cells, which supports the possibility of cross-kingdom transmission [44]. RNA of Flock house virus (FHV), an insect virus first isolated from the grass grub Costelytra zealandica that belongs to the family Nodaviridae, whose members include viruses infecting various invertebrates and vertebrates, has been reported to replicate in plant, insect, yeast and mammalian (baby hamster kidney) cells, and it has been hypothesized that the host components required for FHV replication could be widely conserved [113-119]. In addition, CPMV has been shown to resist and remain infectious to plants after exposure to acid $\mathrm{pH}$ and low concentrations of pepsin [83] and treatment with simulated gastric fluid-containing pepsin at $\mathrm{pH} 2$ or simulated intestinal fluid-containing pancreatin at $\mathrm{pH} 6.8$, suggesting stability for this virus in the gastrointestinal tract [84]. CPMV was demonstrated to be capable of entering the bloodstream and disseminating through systemic trafficking [84], as the presence of the virus was observed in many different organs, such as the spleen, kidney, lung, stomach, duodenum, jejunum, ileum, lymph node, brain, bone marrow and blood, over three days following mouse inoculation. Although replication of a plant virus in mammalian cells was not demonstrated without requiring expression of a genuine host protein, a study reported in 2005 that overexpression of Frankliniella occidentalis encoded putative transcription factors in two human cell lines, human epithelial carcinoma (HeLa) cells and diploid fibroblasts, made these cells permissive for the replication of TWSV [120].

\section{Conclusions}

Previous findings suggest that the border between plants and mammals including humans may be less strict for plant viruses than currently described (Figure 1). Mankind has likely been considerably exposed to plant viruses for several thousand years, and this supports the paradigm that these viruses are safe for humans. Alternatively, if a plant virus was to completely breakdown the host specificity border and become able to multiply in vertebrates, this multiplication could remain unnoticed if it is not associated with a specific symptomatology and could also remain an evolutionary dead-end for the virus if there is no further transmission to vertebrates. Certainly, no evidence that plant viruses are causative agents of disease in humans and other animals has been revealed to date. A very limited number of published studies have been designed to address the issue of the potential pathogenicity of phytoviruses in humans. On the contrary, modified plant viruses, such as TMV, PVX, CMV, PapMV and CPMV have been used recently in new vaccine approaches [121-128]. Overall, previous data indicate that the role of plant viruses as potential human pathogens deserves to be specifically studied further. In particular, this possible role may be deciphered by studying whether and how plant viruses may interact with human cells, which might not necessarily be associated with viral replication in permissive host cells but might involve modulation of gene expression in human cells through RNA interference mechanisms [129].

\section{Author Contributions}

D.R. and P.C. outlined the article. All the authors contributed to the redaction of the article. 


\section{Conflicts of Interest}

The authors declare no conflict of interest.

\section{References}

1. Soosaar, J.L.; Burch-Smith, T.M.; Dinesh-Kumar, S.P. Mechanisms of plant resistance to viruses. Nat. Rev. Microbiol. 2005, 3, 789-798.

2. Ivanovski, D. Concerning the mosaic disease of tobacco plant. St. Petersb. Acad. Imp. Sci. Bul. 1892, 67-70.

3. Beijerinck, M.W. Concerning a contagium vivum fluidum as a cause of the spot-disease of tobacco leaves. Verh. Akad. Wet. Amster. 1898, 6, 33-55.

4. International Committee on Taxonomy of Viruses. Available online: http://ictvonline.org/virus taxonomy.asp (accessed on 20 March 2015).

5. Wren, J.D.; Roossinck, M.J.; Nelson, R.S.; Scheets, K.; Palmer, M.W.; Melcher, U. Plant virus biodiversity and ecology. PLoS Biol. 2006, 4, e80.

6. Giampetruzzi, A.; Roumi, V.; Roberto, R.; Malossini, U.; Yoshikawa, N.; la, N.P.; Terlizzi, F.; Credi, R.; Saldarelli, P. A new grapevine virus discovered by deep sequencing of virus- and viroid-derived small RNAs in Cv Pinot gris. Virus Res. 2012, 163, 262-268.

7. Raoult, D.; Forterre, P. Redefining viruses: Lessons from Mimivirus. Nat. Rev. Microbiol. 2008, 6, 315-319.

8. Desnues, C.; Boyer, M.; Raoult, D. Sputnik, a virophage infecting the viral domain of life. Adv. Virus Res. 2012, 82, 63-89.

9. Desnues, C.; Raoult, D. Virophages question the existence of satellites. Nat. Rev. Microbiol. 2012, $10,234$.

10. Hogenhout, S.A.; Ammar, E.; Whitfield, A.E.; Redinbaugh, M.G. Insect vector interactions with persistently transmitted viruses. Annu. Rev. Phytopathol. 2008, 46, 327-359.

11. Keller, M. Les virus de plantes et les virus des animaux: Deux mondes totalement différents? Virologie 2004, 8, 251-257.

12. Raccah, B. Fereres A: Plant Virus Transmission by Insects; John Wiley \& Sons, Ltd.: Chichester, UK, 2009.

13. Klempner, M.S.; Shapiro, D.S. Crossing the species barrier--one small step to man, one giant leap to mankind. N. Engl. J. Med. 2004, 350, 1171-1172.

14. Yamauchi, Y.; Helenius, A. Virus entry at a glance. J. Cell Sci. 2013, 126, 1289-1295.

15. Lazarowitz, S.D. Plant viruses. In Fields Virology, 5th ed.; Fields, B.N., Knipe, D.M., Eds.; Lippincott, Williams \& Wilkins Publishers: Philadelphia, PA, USA, 2006; pp. 641-706.

16. Taliansky, M.; Torrance, L.; Kalinina, N.O. Role of plant virus movement proteins. Methods Mol. Biol. 2008, 451, 33-54.

17. Deom, C.M.; Lapidot, M.; Beachy, R.N. Plant virus movement proteins. Cell 1992, 69, 221-224.

18. Benitez-Alfonso, Y.; Faulkner, C.; Ritzenthaler, C.; Maule, A.J. Plasmodesmata: Gateways to local and systemic virus infection. Mol. Plant Microbe Interact. 2010, 23, 1403-1412. 
19. Hohn, T. Plant virus transmission from the insect point of view. Proc. Natl. Acad. Sci. USA 2007, 104, 17905-17906.

20. Gaedigk, K.; Adam, G.; Mundry, K.W. The spike protein of Potato yellow dwarf virus and its functional role in the infection of insect vector cells. J. Gen. Virol. 1986, 67, 2763-2773.

21. Tomaru, M.; Maruyama, W.; Kikuchi, A.; Yan, J.; Zhu, Y.; Suzuki, N.; Isogai, M.; Oguma, Y.; Kimura, I.; Omura, T. The loss of outer capsid protein P2 results in nontransmissibility by the insect vector of rice dwarf phytoreovirus. J. Virol. 1997, 71, 8019-8023.

22. Hebrard, E.; Froissart, R.; Louis, C.; Blanc, S. Les modes de transmission des virus phytopathogènes par vecteurs. Virologie 1999, 3, 25-48.

23. Perry, K.L.; Zhang, L.; Palukaitis, P. Amino acid changes in the coat protein of cucumber mosaic virus differentially affect transmission by the aphids Myzus persicae and Aphis gossypii. Virology 1998, 242, 204-210.

24. Diaz-Pendon, J.A.; Canizares, M.C.; Moriones, E.; Bejarano, E.R.; Czosnek, H.; Navas-Castillo, J. Tomato yellow leaf curl viruses: Menage a trois between the virus complex, the plant and the whitefly vector. Mol. Plant Pathol. 2010, 11, 441-450.

25. Ghanim, M.; Morin, S.; Zeidan, M.; Czosneck, H. Evidence for transovarial transmission of tomato yellow leaf curl virus by its vector, the whitefly Bemisia tabaci. Virology 1998, 240, 295-303.

26. Bosco, D.; Mason, G.; Accotto, G.P. TYLCSV DNA, but not infectivity, can be transovarially inherited by the progeny of the whitefly vector Bemisia tabaci (Gennadius). Virology 2004, 323, 276-283.

27. Sylvester, E.S. Circulative and propagative virus transmission by aphids. Ann. Rev. Entomol. 1980, $25,257-286$.

28. Stafford, C.A.; Walker, G.P.; Ullman, D.E. Infection with a plant virus modifies vector feeding behavior. Proc. Natl. Acad. Sci. USA 2011, 108, 9350-9355.

29. Rubinstein, G.; Czosnek, H. Long-term association of tomato yellow leaf curl virus with its whitefly vector Bemisia tabaci: Effect on the insect transmission capacity, longevity and fecundity. J. Gen. Virol. 1997, 78, 2683-2689.

30. Li, J.L.; Cornman, R.S.; Evans, J.D.; Pettis, J.S.; Zhao, Y.; Murphy, C.; Peng, W.J.; Wu, J.; Hamilton, M.; Boncristiani, H.F., Jr.; et al. Systemic Spread and Propagation of a Plant-Pathogenic Virus in European Honeybees, Apis mellifera. MBio 2014, 51, e00898-13.

31. Koonin, E.V. The origin and early evolution of eukaryotes in the light of phylogenomics. Genome Biol. 2010, 11, 209-211.

32. Roger, A.J.; Simpson, A.G. Evolution: Revisiting the root of the eukaryote tree. Curr. Biol. 2009, 19, R165-R167.

33. Tamura, K.; Peterson, D.; Peterson, N.; Stecher, G.; Nei, M.; Kumar, S. MEGA5: molecular evolutionary genetics analysis using maximum likelihood, evolutionary distance, and maximum parsimony methods. Mol. Biol. Evol. 2011; 28, 2731-2739.

34. Benson, D.A.; Clark, K.; Karsch-Mizrachi, I.; Lipman, D.J.; Ostell, J.; Sayers, E.W. GenBank. Nucleic Acids Res. 2015; 43, D30-D35. 
35. Maroniche, G.A.; Mongelli, V.C.; Peralta, A.V.; Distefano, A.J.; Llauger, G.; Taboga, O.A.; Hopp, E.H.; del, V.M. Functional and biochemical properties of Mal de Rio Cuarto virus (Fijivirus, Reoviridae) P9-1 viroplasm protein show further similarities to animal reovirus counterparts. Virus Res. 2010, 152, 96-103.

36. Choi, U.Y.; Lee, S.Y.; Ma, S.H.; Jang, Y.T.; Kim, J.Y.; Kim, H.M.; Kim, J.H.; Kim, D.S.; Kim, Y.S.; Kang, J.H. Epidemiological changes in rotavirus gastroenteritis in children under 5 years of age after the introduction of rotavirus vaccines in Korea. Eur. J. Pediatr. 2013, 172, 947-952.

37. Tordo, N.; Ceccaldi, P.-E.; Gaudin, Y.; Wandeler, A.I. Rhabdoviruses: Rabies. In Topley and Wilson's Microbiology and Microbial Infections; Mahy, B.W.J., Collier, L., Eds.; 2010; pp. 665-692.

38. Kallio-Kokko, H.; Laakkonen, J.; Rizzoli, A.; Tagliapietra, V.; Cattadori, I.; Perkins, S.E.; Hudson, P.J.; Cristofolini, A.; Versini, W.; Vapalahti, O.; et al. Hantavirus and arenavirus antibody prevalence in rodents and humans in Trentino, Northern Italy. Epidemiol. Infect. 2006, 134, 830-836.

39. Sonderegger, B.; Hachler, H.; Dobler, G.; Frei, M. Imported aseptic meningitis due to Toscana virus acquired on the island of Elba, Italy, August 2008. Euro. Surveill. 2009, 14, e19079.

40. Charrel, R.N.; Gallian, P.; Navarro-Mari, J.M.; Nicoletti, L.; Papa, A.; Sanchez-Seco, M.P.; Tenorio, A.; de Lamballerie, X. Emergence of Toscana virus in Europe. Emerg. Infect. Dis. 2005, $11,1657-1663$.

41. Niehl, A.; Heinlein, M. Cellular pathways for viral transport through plasmodesmata. Protoplasma 2011, 248, 75-99.

42. Mead, D.G.; Gray, E.W.; Noblet, R.; Murphy, M.D.; Howerth, E.W.; Stallknecht, D.E. Biological transmission of vesicular stomatitis virus (New Jersey serotype) by Simulium vittatum (Diptera: Simuliidae) to domestic swine (Sus scrofa). J. Med. Entomol. 2004, 41, 78-82.

43. Lin, T.; Clark, A.J.; Chen, Z.; Shanks, M.; Dai, J.B.; Li, Y.; Schmidt, T.; Oxelfelt, P.; Lomonossoff, G.P.; Johnson, J.E. Structural fingerprinting: Subgrouping of comoviruses by structural studies of red clover mottle virus to 2.4-A resolution and comparisons with other comoviruses. J. Virol. 2000, 74, 493-504.

44. Koudelka, K.J.; Destito, G.; Plummer, E.M.; Trauger, S.A.; Siuzdak, G.; Manchester, M. Endothelial targeting of cowpea mosaic virus (CPMV) via surface vimentin. PLoS Pathog. 2009, 5 , e1000417.

45. Geering, A.D.; Scharaschkin, T.; Teycheney, P.Y. The classification and nomenclature of endogenous viruses of the family Caulimoviridae. Arch. Virol. 2010, 155, 123-131.

46. Koonin, E.V. The phylogeny of RNA-dependent RNA polymerases of positive-strand RNA viruses. J. Gen. Virol. 1991, 72, 2197-2206.

47. Cui, J.; Holmes, E.C. Endogenous RNA viruses of plants in insect genomes. Virology 2012, 427, 77-79.

48. Dolja, V.V.; Koonin, E.V. Common origins and host-dependent diversity of plant and animal viromes. Curr. Opin. Virol. 2011, 1, 322-331.

49. Ng, K.K.; Arnold, J.J.; Cameron, C.E. Structure-function relationships among RNA-dependent RNA polymerases. Curr. Top. Microbiol. Immunol. 2008, 320, 137-156. 
50. Novick, R.P. Contrasting lifestyles of rolling-circle phages and plasmids. Trends Biochem. Sci. 1998, 23, 434-438.

51. Ilyina, T.V.; Koonin, E.V. Conserved sequence motifs in the initiator proteins for rolling circle DNA replication encoded by diverse replicons from eubacteria, eucaryotes and archaebacteria. Nucleic Acids Res. 1992, 20, 3279-3285.

52. Gibbs, M.J.; Weiller, G.F. Evidence that a plant virus switched hosts to infect a vertebrate and then recombined with a vertebrate-infect ing virus. Proc. Natl. Acad. Sci. USA 1999, 96, 8022-8027.

53. Davidson, I.; Silva, R.F. Creation of diversity in the animal virus world by inter-species and intraspecies recombinations: Lessons learned from poultry viruses. Virus Genes 2008, 36, 1-9.

54. Flores, R.; Hernandez, C.; Martinez de Alba, A.E.; Daros, J.A.; di, S.F. Viroids and viroid-host interactions. Annu. Rev. Phytopathol. 2005, 43, 117-139.

55. Flores, R.; Ruiz-Ruiz, S.; Serra, P. Viroids and hepatitis delta virus. Semin. Liver Dis. 2012, 32, 201-210.

56. Daros, J.A.; Elena, S.F.; Flores, R. Viroids: An Ariadne's thread into the RNA labyrinth. $E M B O$ Rep. 2006, 7, 593-598.

57. Brazas, R.; Ganem, D. A cellular homolog of hepatitis delta antigen: Implications for viral replication and evolution. Science 1996, 274, 90-94.

58. Robertson, H.D. How did replicating and coding RNAs first get together? Science 1996, 274, 66-67.

59. Hu, Q.; Niu, Y.; Zhang, K.; Liu, Y.; Zhou, X. Virus-derived transgenes expressing hairpin RNA give immunity to Tobacco mosaic virus and Cucumber mosaic virus. Virol. J. 2011, 8, e41.

60. Tomlinson, J.A.; Faithfull, E.; Flewett, T.H.; Beards, G. Isolation of infective tomato bushy stunt virus after passage through the human alimentary tract. Nature 1982, 300, 637-638.

61. Hollings, M.; Stone, O.M. Studies of pelargonium leaf curl virus. Ann. Appl. Biol. 1965, 56, 87-98.

62. Colson, P.; Richet, H.; Desnues, C.; Balique, F.; Moal, V.; Grob, J.J.; Berbis, P.; Lecoq, H.; Harle, J.R.; Berland, Y.; et al. Pepper mild mottle virus, a plant virus associated with specific immune responses, Fever, abdominal pains, and pruritus in humans. PLoS One 2010, 5, e10041.

63. World Health Organization media centre, fact sheets. Available online: http://www.who.int/ mediacentre/factsheets/2003/fs134/en/ (accessed on 20 March 2015).

64. Bothwell, P.W. Lung cancer and tobacco mosaic virus. Lancet 1960, 1, 657-658.

65. Wahyuni, W.S.; Hanapi, M.; Hartana, I. The Presence of tobacco mosaic virus in the compost extract of Cigar Tobacco Debris. J. Biosci. 2008, 15, 118-22.

66. Wetter, C. Tobacco mosaic virus and para-tobacco mosaic virus in cigarettes. Naturwissenschaften 1975, 62, 533.

67. Chyle, P.; Chyle, M.; Korb, J.; Papanek, M. Virus tabakove mozaiky, polyfenoly a kancerogenita tabakoveho navyku. Cesk Epidemiol. Mikrobiol. Imunol. 1971, 20, 32-42.

68. Smith, K.M. A Textbook of Plant Virus Diseases. Elsevier: London, UK, 1957; p. 507.

69. Balique, F.; Colson, P.; Raoult, D. Tobacco mosaic virus in cigarettes and saliva of smokers. J. Clin. Virol. 2012, 55, 374-376.

70. Rosario, K.; Nilsson, C.; Lim, Y.W.; Ruan, Y.; Breitbart, M. Metagenomic analysis of viruses in reclaimed water. Environ. Microbiol. 2009, 11, 2806-2820. 
71. Stepanova, O.A.; Solovyova, Y.V.; Solovyov, A.V. Results of algae viruses search in human clinical material. Ukrainica Bioorganica Acta 2011, 2, 53-56.

72. Yolken, R.H.; Jones-Brando, L.; Dunigan, D.D.; Kannan, G.; Dickerson, F.; Severance, E.; Sabunciyan, S.; Talbot, C.C., Jr.; Prandovszky, E.; Gurnon, J.R.; et al. Chlorovirus ATCV-1 is part of the human oropharyngeal virome and is associated with changes in cognitive functions in humans and mice. Proc. Natl. Acad. Sci. USA 2014, 111, 16106-16111.

73. Jacobi, V.; Castello, J. Isolation of tomato mosaic virus from waters draining forest stands in New york state. Phytopathology 1991, 81, 1112-1117.

74. Castello, J.D.; Rogers, S.O.; Starmer, W.T.; Catranis, C.M.; Ma, L.; Bachand, G.D.; Zhao, Y.; Smith, J.E. Detection of tomato mosaic tobamovirus RNA in ancient glacial ice . Polar biol. 1999, 22, 207-212.

75. Castello, J.D.; Lakhsman, D.K.; Tavantzis, S.M.; Rogers, S.O.; Bachand, G.D.; Jagels, R.J.; Carlisle, J.; Liu, Y. Detection of infectious tomato mosaic tobamovirus in fog and clouds. Phytopathology 1995, 85, 1409-1412.

76. Rosario, K.; Symonds, E.M.; Sinigalliano, C.; Stewart, J.; Breitbart, M. Pepper mild mottle virus as an indicator of fecal pollution. Appl. Environ. Microbiol. 2009, 75, 7261-7267.

77. Hamza, I.A.; Jurzik, L.; Uberla, K.; Wilhelm, M. Methods to detect infectious human enteric viruses in environmental water samples. Int. J. Hyg. Environ. Health 2011, 214, 424-436.

78. Haramoto, E.; Kitajima, M.; Kishida, N.; Konno, Y.; Katayama, H.; Asami, M.; Akiba, M. Occurrence of pepper mild mottle virus in drinking water sources in Japan. Appl. Environ. Microbiol. 2013, 79, 7413-7418.

79. Tomlinson, J.A.; Faithfull, E. Studies on the occurrence of tomato bushy stunt virus in English rivers. Ann. Appl. Biol. 1984, 104, 485-495.

80. Kramberger, P.; Peterka, M.; Boben, J.; Ravnikar, M.; Strancar, A. Short monolithic columns-A breakthrough in purification and fast quantification of tomato mosaic virus. J. Chromatogr. A 2007, 1144, 143-149.

81. Gosalvez, B.; Navarro, J.A.; Lorca, A.; Botella, F.; Sanchez-Pina, M.A.; Pallas, V. Detection of melon necrotic spot virus in water samples and melon plants by molecular methods. J. Virol. Methods 2003, 113, 87-93.

82. Vani, S.; Varma, A. Properties of cucumber green mottle mosaic virus isolated from water of river Yamuna. Indian Phytopathol. 1993, 46, 118-122.

83. Xu, F.; Jones, T.D.; Rodgers, P.B. Potential of chimaeric plant virus particles as novel, stable vaccines. Dev. Biol. Stand. 1996, 87, 201-205.

84. Rae, C.S.; Khor, I.W.; Wang, Q.; Destito, G.; Gonzalez, M.J.; Singh, P.; Thomas, D.M.; Estrada, M.N.; Powell, E.; Finn, M.G.; et al. Systemic trafficking of plant virus nanoparticles in mice via the oral route. Virology 2005, 343, 224-235.

85. Phan, T.G.; Kapusinszky, B.; Wang, C.; Rose, R.K.; Lipton, H.L.; Delwart, E.L. The fecal viral flora of wild rodents. PLoS Pathog. 2011, 7, e1002218.

86. Zhang, T.; Breitbart, M.; Lee, W.H.; Run, J.Q.; Wei, C.L.; Soh, S.W.; Hibberd, M.L.; Liu, E.T.; Rohwer, F.; Ruan, Y. RNA viral community in human feces: Prevalence of plant pathogenic viruses. PLoS Biol. 2006, 4, e3. 
87. Nakamura, S.; Yang, C.S.; Sakon, N.; Ueda, M.; Tougan, T.; Yamashita, A.; Goto, N.; Takahashi, K.; Yasunaga, T.; Ikuta, K.; et al. Direct metagenomic detection of viral pathogens in nasal and fecal specimens using an unbiased high-throughput sequencing approach. PLoS One 2009, 4, e4219.

88. Li, L.; Victoria, J.G.; Wang, C.; Jones, M.; Fellers, G.M.; Kunz, T.H.; Delwart, E. Bat guano virome: Predominance of dietary viruses from insects and plants plus novel mammalian viruses. J. Virol. 2010, 84, 6955-6965.

89. Sarra, S.; Peters, D. Rice yellow mottle virus is transmitted by cows, donkeys, and grass Rats in irrigated rice crops. Plant Dis. 2003, 87, 804-808.

90. MCkirdy, S.J.; Jones, R.A.C.; Sivasithamparam, K. Dertermining the effectiveness of grazing and trampling by livestock in transmitting white clover mosaic and subterranean clover mottle virus. Ann. Appl. Biol. 1998, 132, 91-105.

91. Li, L.; Wang, L.; Xiao, R.; Zhu, G.; Li, Y.; Liu, C.; Yang, R.; Tang, Z.; Li, J.; Huang, W.; et al. The invasion of tobacco mosaic virus RNA induces endoplasmic reticulum stress-related autophagy in HeLa cells. Biosci. Rep. 2012, 32, 171-186.

92. Balique, F.; Colson, P.; Barry, A.O.; Nappez, C.; Ferretti, A.; Moussawi, K.A.; Ngounga, T.; Lepidi, H.; Ghigo, E.; Mege, J.L.; et al. Tobacco Mosaic Virus in the Lungs of Mice following Intra-Tracheal Inoculation. PLoS One 2013, 8, e54993.

93. McCormick, A.A.; Corbo, T.A.; Wykoff-Clary, S.; Palmer, K.E.; Pogue, G.P. Chemical conjugate TMV-peptide bivalent fusion vaccines improve cellular immunity and tumor protection. Bioconjug. Chem. 2006, 17, 1330-1338.

94. Katsilambros, L. Tobacco mosaic virus and lung cancer. Lancet 1960, 2, 934.

95. LeClair, R.A. Recovery of culturable tobacco mosaic virus from sputum and thoracentesis fluids obtained from cigarette smokers with a history of pulmonary disease. Am. Rev. Respir. Dis. 1967, $95,510-511$.

96. Van Dorst, H.J.M. Surface water as source in the spread of cucumber green mottle mosaic virus. Neth. J. Agric. Sci. 1988, 36, 291-299.

97. Hamza, I.A.; Jurzik, L.; Uberla, K.; Wilhelm, M. Evaluation of pepper mild mottle virus, human picobirnavirus and Torque teno virus as indicators of fecal contamination in river water. Water Res. 2011, 45, 1358-1368.

98. Bothwell, P.W. Lung cancer and tobacco mosaic virus. Lancet 1960, 1, 923-924.

99. Pirié, N.W. Lung cancer and tobacco mosaic virus. Lancet 1960, 1, 707.

100. Pirié, N.W. Lung cancer and tobacco mosaic virus. Lancet 1960, 1, 978-979.

101. Carpenter, C.M.; le Clair, R. Tobacco mosaic virus and pulmonary diseases of humans. Dis. Chest 1968, 54, 42-43.

102. Falk, H.L. Chemical agents in cigarette smoke. In Handbook of Physiology; Lee, D.H.K., Ed.; 2011; pp. 199-211.

103. Chyle, P.; Chyle, M.; Patocka, F. Virus tabakove mozaiky a polyfenoly jako priorozene se vyskytujici kancerogeny v Tabaku. Casopis Lekaru Ceskych 1971, 110, 189-190.

104. Bousbia, S.; Papazian, L.; La, S.B.; Raoult, D. Detection of plant DNA in the bronchoalveolar lavage of patients with ventilator-associated pneumonia. PLoS One 2010, 5, e11298. 
105. Victoria, J.G.; Kapoor, A.; Li, L.; Blinkova, O.; Slikas, B.; Wang, C.; Naeem, A.; Zaidi, S.; Delwart, E. Metagenomic analyses of viruses in stool samples from children with acute flaccid paralysis. J. Virol. 2009, 83, 4642-4651.

106. Medeiros, R.B.; Resende, R.O.; de Avila, A.C. The plant virus Tomato Spotted Wilt Tospovirus activates the immune system of its main insect vector, Frankliniella occidentalis. J. Virol. 2004, 78, 4976-4982.

107. Florindo, M.I.; de Aragao, M.E.; da Silva, A.C.; Otoch, M.L.; Melo, D.F.; Lima, J.A.; Lima, M.G. Immune response induced in mice oral immunization with cowpea severe mosaic virus. Braz. J. Med Biol. Res. 2002, 35, 827-835.

108. Friedland, R.P.; Tedesco, J.M.; Wilson, A.C.; Atwood, C.S.; Smith, M.A.; Perry, G.; Zagorski, M.G. Antibodies to potato virus Y bind the amyloid beta peptide: Immunohistochemical and NMR studies. J. Biol. Chem. 2008, 283, 22550-22556.

109. Liu, R.; Vaishnav, R.A.; Roberts, A.M.; Friedland, R.P. Humans have antibodies against a plant virus: Evidence from tobacco mosaic virus. PLoS One 2013, 8, e60621.

110. Knowland, J. Protein synthesis directed by the RNA from a plant virus in a normal animal cell. Genetics 1974, 78, 383-394.

111. Nedellec, P.; Vicart, P.; Laurent-Winter, C.; Martinat, C.; Prevost, M.C.; Brahic, M. Interaction of Theiler's virus with intermediate filaments of infected cells. J. Virol. 1998, 72, 9553-9560.

112. Kim, J.K.; Fahad, A.M.; Shanmukhappa, K.; Kapil, S. Defining the cellular target(s) of porcine reproductive and respiratory syndrome virus blocking monoclonal antibody 7G10. J. Virol. 2006, 80, 689-696.

113. Albarino, C.G.; Price, B.D.; Eckerle, L.D.; Ball, L.A. Characterization and template properties of RNA dimers generated during flock house virus RNA replication. Virology 2001, 289, 269-282.

114. Dasgupta, R.; Cheng, L.L.; Bartholomay, L.C.; Christensen, B.M. Flock house virus replicates and expresses green fluorescent protein in mosquitoes. J. Gen. Virol. 2003, 84, 1789-1797.

115. Price, B.D.; Eckerle, L.D.; Ball, L.A.; Johnson, K.L. Nodamura virus RNA replication in Saccharomyces cerevisiae: Heterologous gene expression allows replication-dependent colony formation. J. Virol. 2005, 79, 495-502.

116. Ball, L.A. Requirements for the self-directed replication of flock house virus RNA 1. J. Virol. 1995, 69, 720-727.

117. Gallagher, T.M.; Rueckert, R.R. Assembly-dependent maturation cleavage in provirions of a small icosahedral insect ribovirus. J. Virol. 1988, 62, 3399-3406.

118. Miller, D.J.; Schwartz, M.D.; Ahlquist, P. Flock house virus RNA replicates on outer mitochondrial membranes in Drosophila cells. J. Virol. 2001, 75, 11664-11676.

119. Johnson, K.L.; Ball, L.A. Replication of flock house virus RNAs from primary transcripts made in cells by RNA polymerase II. J. Virol. 1997, 71, 3323-3327.

120. De Medeiros, R.B.; Figueiredo, J.; Resende, R.O.; de Avila, A.C. Expression of a viral polymerasebound host factor turns human cell lines permissive to a plant- and insect-infecting virus. Proc. Natl. Acad. Sci. USA 2005, 102, 1175-1180.

121. Yusibov, V.; Shivprasad, S.; Turpen, T.H.; Dawson, W.; Koprowski, H. Plant viral vectors based on tobamoviruses. Curr. Top. Microbiol. Immunol. 1999, 240, 81-94. 
122. Gilleland, H.E.; Gilleland, L.B.; Staczek, J.; Harty, R.N.; Garcia-Sastre, A.; Palese, P.; Brennan, F.R.; Hamilton, W.D.; Bendahmane, M.; Beachy, R.N. Chimeric animal and plant viruses expressing epitopes of outer membrane protein $\mathrm{F}$ as a combined vaccine against Pseudomonas aeruginosa lung infection. FEMS Immunol. Med. Microbiol. 2000, 27, 291-297.

123. Marusic, C.; Rizza, P.; Lattanzi, L.; Mancini, C.; Spada, M.; Belardelli, F.; Benvenuto, E.; Capone, I. Chimeric plant virus particles as immunogens for inducing murine and human immune responses against human immunodeficiency virus type 1. J. Virol. 2001, 75, 8434-8439.

124. Nuzzaci, M.; Vitti, A.; Condelli, V.; Lanorte, M.T.; Tortorella, C.; Boscia, D.; Piazzolla, P.; Piazzolla, G. In vitro stability of Cucumber mosaic virus nanoparticles carrying a Hepatitis C virusderived epitope under simulated gastrointestinal conditions and in vivo efficacy of an edible vaccine. J. Virol. Methods 2010, 165, 211-215.

125. Savard, C.; Guerin, A.; Drouin, K.; Bolduc, M.; Laliberte-Gagne, M.E.; Dumas, M.C.; Majeau, N.; Leclerc, D. Improvement of the trivalent inactivated flu vaccine using PapMV nanoparticles. PLoS One 2011, 6, e21522.

126. Brennan, F.R.; Gilleland, L.B.; Staczek, J.; Bendig, M.M.; Hamilton, W.D.; Gilleland, H.E., Jr. A chimaeric plant virus vaccine protects mice against a bacterial infection. Microbiology 1999, 145, 2061-2067.

127. Porta, C.; Lomonossoff, G.P. Scope for using plant viruses to present epitopes from animal pathogens. Rev. Med. Virol. 1998, 8, 25-41.

128. Lacasse, P.; Denis, J.; Lapointe, R.; Leclerc, D.; Lamarre, A. Novel plant virus-based vaccine induces protective cytotoxic T-lymphocyte-mediated antiviral immunity through dendritic cell maturation. J. Virol. 2008, 82, 785-794.

129. Rebolledo-Mendez, J.D.; Vaishnav, R.A.; Cooper, N.G.; Friedland, R.P. Cross-kingdom sequence similarities between human micro-RNAs and plant viruses. Commun. Integr. Biol. 2013, 6, e24951.

(C) 2015 by the authors; licensee MDPI, Basel, Switzerland. This article is an open access article distributed under the terms and conditions of the Creative Commons Attribution license (http://creativecommons.org/licenses/by/4.0/). 